\title{
The SWOT Analysis, Tool for Commensurate the Involvement of the Evaluator Students in Quality Assurance System from Romanian Agricultural and Veterinary Higher Education
}

\author{
Sorina DÂRJAN, Emilian MERCE, Ioana POP*, Antonia ODAGIU \\ University of Agricultural Sciences and Veterinary Medicine Cluj-Napoca, 3-5 Manastur St., 400372 \\ Cluj - Napoca, Romania; \\ * corresponding author: ioana.pop@usamvcluj.ro
}

Bulletin USAMV series Agriculture 72(1)/2015

Print ISSN 1843-5246; Electronic ISSN 1843-5386

DOI 10.15835/buasvmcn-agr: 11176

\begin{abstract}
Because education assurance and assessment represent integrant components for the competitivity increasing within higher education system, the students' opinion imposes itself as an essential component. Given this reality, our study aims to perform the SWOT Analysis for quality assurance process, according to the compared vision of students evaluators from Romanian agricultural sciences and veterinary medicine universities (UASVM), in order to highlight on scientific basis, the efficacy of the implementation stage of the quality system in education at each analysed university, also for identifying the most important strategic choices at university level. Our study was implemented in the Universities of Agricultural Sciences and Veterinary Medicine from Cluj - Napoca, Timisoara, Iasi, and University of Agronomic Sciences and Veterinary Medicine from Bucharest. The data used in the SWOT Analysis are public data, resulted from external institutional evaluation of the academic quality, performed when visits of evaluator teams occurred. The evaluators were: ARACIS (The Romanian Agency for Quality Assurance in Higher Education) experts, student experts and a foreign evaluator. The results of the SWOT Analysis indicate unitary character of the educational process, as well as functionality of the quality system in Universities of Agricultural Sciences and Veterinary Medicine from Cluj - Napoca, Timisoara, Iasi, and University of Agronomic Sciences and Veterinary Medicine from Bucharest. In these educational institutions, the specific component of the student evaluators' involvement have adequate importance by contributing to improvement and development of the strategic visions of the reference institutions.
\end{abstract}

Keywords: analysis, threats, opportunities, strong points, weak points, system.

\section{INTRODUCTION}

The continuous developments of the academic field led to changing the vision and perspective concerning quality assurance in higher education, and quality assurance and assessment are important aspects in the process of increasing the competitiveness of higher education (Federkeil, 2008; Bratean et al., 2013). The quality of education, defined as a set of characteristics of a study program and education provider in which, are met the beneficiary expectations and quality standards (http://www.aracis.ro/fileadmin/ ARACIS/ Publicatii_Aracis/brosuri/brosu ra USMAV_pt._BT.pdf), is the starting premise of higher education performance analysis, according to ARACIS (The Romanian Agency for Quality Assurance in Higher Education) standards (http:// proiecte.aracis.ro/fileadmin/ARACIS /Publicatii_ Aracis/Brosuri proiect/Etapa_III/Brosuri _proiect/ Aracis_46_interoir_mail.pdf; http:// proiecte. aracis.ro /fileadmin/ARACIS/Publicatii_ 
Aracis/Brosuri_proiect/Etapa_II

/Brosuri proiect/Aracis_Interior_Med_Vet_Cluj_34_mail_2. pdf; http://www.aracis.ro/uploads/media/ Raport_Director_de_misiune_si_coordonator_81. pdf;http://mobile.www.aabri.com/ manuscr ipts/ 09403.pdf).

In this context, both essential attributes of quality, assessment and assurance, respectively must be highlighted (EU, 2012). Thus, if the quality assessment consists in multi-criteria examination of the extent to which the education provider and its programs meet the benchmarks, the quality assurance concerns: institutional capacity, educational effectiveness and quality management (http://vrtl12546.servidoresdns. net/sites/default/ files/rankings-and-qualityassurance-higher-eduhttp://www.invatamantsuperior.ro/wp-cont ent/uploads/2013/08/ Analiza-Functionala-a-Sectorului-cation. pdf;http://vrtl12546. Servidor endns. net/ sites/ default/files/rankings- and-quality-assurancehigher-education.pdf).

At institutional level, the quality assessment of the academic teaching is accomplished through specific instruments (Fig.1), and the quality assurance, by specific performance indicators (ARACIS Standards): educational efficacy, programme of study content programmes of study and relevance of programmes of study (Brătianu and Miroiu, 1999; Ivorschi, 2012).

An important aspect of the quality assessment process in higher education is the students' perception concerning the size of the academic quality, becauseithasadecisiveroleinidentification of the quality and efficacy of a high education institution (Bauman and Lata, 1998 cited by Sum, 2008; McCaskey and Kyeyune, 2010). Practically, as high is the degree of students satisfaction, the

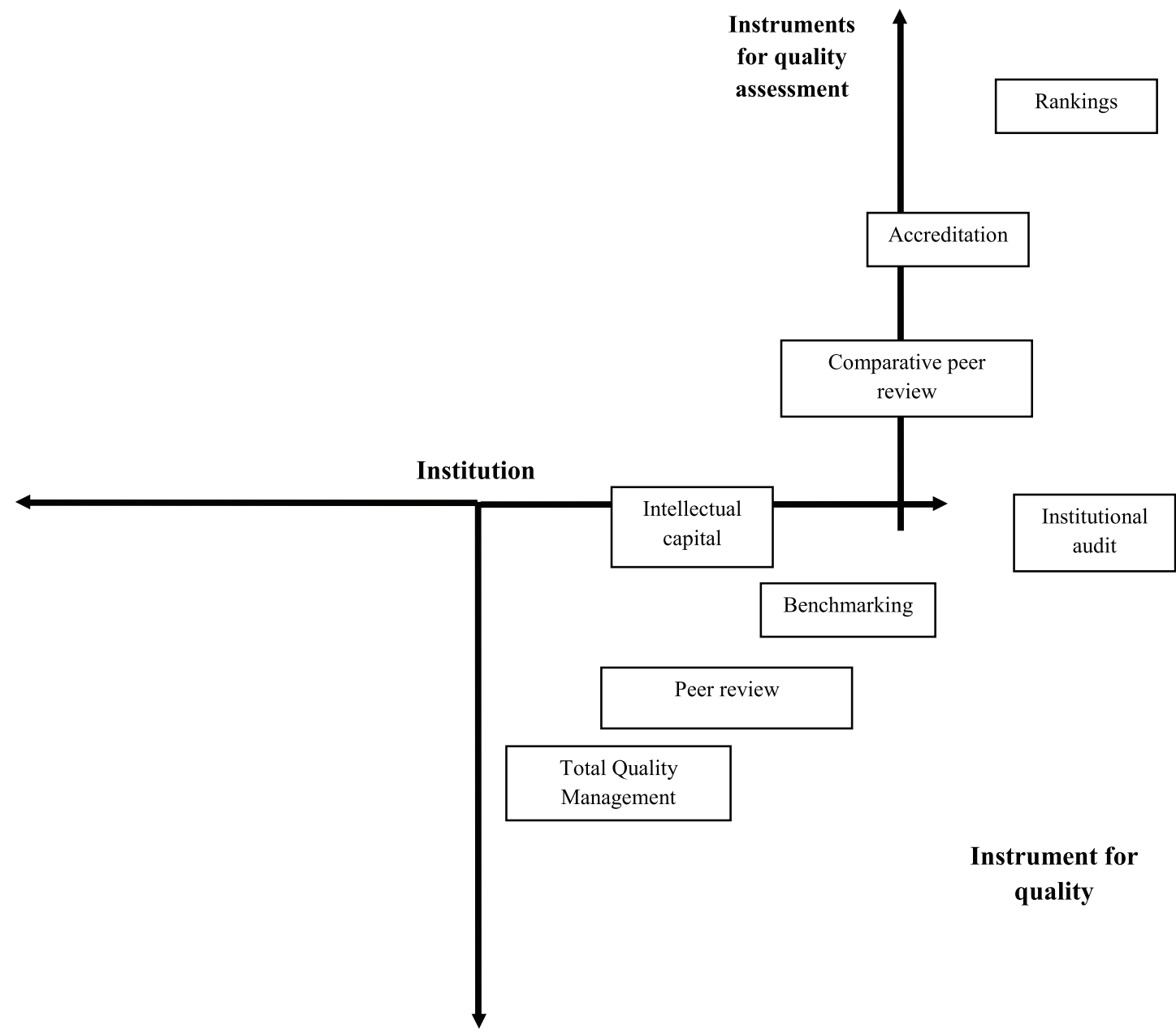

Fig.1. Instruments of quality assessment in higher education

(CHE Ranking data cited by Federkeil, 2008) 
more the students will recommend a program of study to future students (Bauman and Lata, cited by Sum, 2008; McCaskey and Kyeyune, 2010), and higher education institution positively assessed by students will have concurențial advantages compared to other profile institutions assessed by students as having reduced performance quotes (Georgevia, 2008).

As consequence, the identification of the students' requirements allows higher education institutions to attract competitive students, and in the meantime to improve the programme of study quality (Elliott and Shin, 2002). From this point of view, it is vital for educational institutions to identify what is really important and valuable for students, and also what is of significant interest in the assessments and students' satisfaction (Brătianu, 2000)

Given the premises already highlighted, the importance of student opinion is evident, as an essential component in strengthening strategies of universities, but also in the development of new strategies (Juran, 2000). To do this, however, it is necessary that the organizational unit to be fully aware of its strategic position. Or, in this context, the SWOT Analysis is the most useful tool (Fayol, 1979). It consists in highlighting the organization's strengths (S) defining positive values and internal conditionings, which may be sources for organization success in achieving the managerial target; weaknesses (W) and elements that may hinder the achievement of objectives; opportunities (0), or the ways in which the organization interests can be influenced, and threats (T) and the negative aspects arising from the exploitation of resources of the organization, or limitations that are imposed to organization by a changing external environment (European Association for Quality Assurance in Higher Education, 2009).

This is the context in which the present work proposes to perform comparative SWOT Analysis for quality assurance process, according to the vision of students evaluators in higher education institutions of agricultural sciences and veterinary medicine in the country (UASVMs), to emphasize, on scientific basis, the efficacy of the implementation stage of the quality system in education process, at each studied university centre, in order to identify the most important strategic choices at university level

\section{MATERIALS AND METHODS}

The present study was performed within the Universities of Agricultural Sciences and Veterinary Medicine from Cluj - Napoca, Timisoara, Iasi, and University of Agronomic Sciences and Veterinary Medicine from Bucharest, in terms of four indicators: the process of education, infrastructure, methodology of investigation of students' satisfaction degree, and insertion on labour market. The data used in SWOT Analysis, are public data, resulted from the external institutional evaluation of the academic quality, performed by evaluators' teams during their visits. The evaluators' teams consists of ARACIS experts, student assessors, and a foreign expert.

The reports of the student assessors from the professional teams made up of ARACIS experts, are based on usual methodology of data collection (European Student Union Report, 2012), involving: meetings and discussions with students, students' representatives, students' associations, graduates of the involved UASVMs, state and zonal private employers, members of leading staff of the UASVMs, representatives of the Centre of Professional Counselling and Orientation, administration employees. In USAMVs from Iasi and Timisoara, the questionnaire method was also applied. The size of the target group of students, from which we obtained data on the perception of quality in higher education, was not identical in these two universities.

Statistical questionnaire applied by evaluator students on satisfaction factors influencing the quality of services was applied to 190 students from UASVM Bucharest, and to 50 students from USAMV Iasi. We also note that if for UASVM Bucharest we cannot benefit of data in order to perform a completeSWOT Analysis, missing threats and opportunities. In this way, where possible, we have extended the realities highlighted in other universities to this university.

Based on available data, we reformulate the SWOT Analysis, initially performed based on reports of the student assessors, by emphasizing the five primordially issues, of each analysed UASMV , correspondent to the four components of the SWOT Analysis. Corroborating the results of the SWOT Analysis made by us, with recommendations made by the assessors, led to the development of the basic principles, which should lead to the 
formulation of best uniform development strategy of the studied $\boldsymbol{U A S V M}$.

\section{RESULTS AND DISCUSSIONS}

The SWOT Analysis we made on available data, emphasizes both common and divergent issues from the universities of our country with agricultural and veterinary profiles.

Strong points. We note that part of the analysed issues are common in all four studied universities, appropriate infrastructure for practical aptitudes, and good representativeness of students within the university management structures, respectively (Tab. 1). Differences between strong points are recorded in majority of considered issues.

Thus, if for UASVM Cluj-Napoca and UASVM Bucharest implemented e-learning system (platform accessible to students, e-learning blackboard system, on-line teaching, possibilities for video conferences) and quality system implemented at students' level (students are asked about satisfaction concerning the teaching process) are strong points, for $\boldsymbol{U A S V M}$ from Iasi, study mobility and big number of students must be taken in to consideration I, in this respect, and for UASVM Timisoara, existence of an extension unit and head-hunting activity. Also, if within UASVM of Cluj - Napoca, Iasi, and Timisoara the functional relationships with graduates and employees represent in vision of student assessors a strong point, in UASVM Bucharest, students' involvement in research activity is a prevalent/strong point (Tab. 1).

Weak points. The study of the weak points mentioned in our SWOT Analysis, emphasises, apart from strong points, discrepancies between universities (Tab. 1).

Within UASVM Cluj-Napoca, the most important problems are connected to the voluntaries activity (no ECTS procedures), individual professional training stage of students (the individual professional training stage is not recognized), weak promotion of the centre for education in career, organization of students' representativeness (lack of appropriate regulations for students' elections, the representative students' mandate is by 4 years) and social activities management (not all accommodation requirements are satisfied, lack of access systems for persons with disabilities).
Concerning UASVM Bucharest, the weak points are referring to: weak representativeness of voluntaries activities, deficiencies on organizing of secretariat activity (the secretariat clerkshaveshortprogramme), butalsotodeficiency in organizing students' representativeness (e.g. students of hostels committees are nominated by the social department), weak development of relationship with employers in the labour market (lack of meetings with representatives of private employers environment, companies, etc., lack of delivering opportunities for transversal competencies) and lack of appropriate study spaces (lecture rooms, over - accommodation).

UASVM Iasi has deficiencies concerning ECTS and textbook supports (students are not enough informed concerning the significance of ECTS, at least $30 \%$ of total ECTS accumulated by students, in the end of the study programme, result from freely chosen disciplines; not all teaching staff provide free textbooks), professional training activity (the professional training programme is not a supervised process, nor diversified, need to improve the relationship with employers (no demand for employers feed-back concerning the students performances during their training programme), deficiency in organizing students' representativeness (teaching staff are part of the students' electoral commission) and lack of appropriate study spaces (small number of places in lecture rooms).

The characteristics of the weak points emphasized within UASVM Timisoara, are represented by deficiencies in students' professional training preparation, according to employers, low number of external mobility, weak development o of relationship with employers, weak informatics competencies and students inability of using specific software packages delivered by teaching staff (Tab. 1).

opportunities. If concerning strong points and weak points, much or less substantial discrepancies were recorded between analysed universities (Tab. 1), according to the vision of the student assessors, concerning the opportunities, there are, in a large majority, identical, and can be synthetized, as follows: alignment to Bologna system (modernization of the educational system and opportunities of study recognition in EU), intensifying the activities of long-life learning, partnerships and international cooperation 
Tab. 1. The SWOT Analysis for the quality assurance process, based on student assessors vision, in UASVMs from Cluj-Napoca, Bucharest, Iasi, and Timisoara

\begin{tabular}{|c|c|c|c|}
\hline $\begin{array}{c}\text { UASVM } \\
\text { Cluj - Napoca }\end{array}$ & $\begin{array}{c}\text { UASVM } \\
\text { Bucharest }\end{array}$ & $\begin{array}{l}\text { UASVM } \\
\text { Iasi }\end{array}$ & $\begin{array}{c}\text { UASVM } \\
\text { Timisoara }\end{array}$ \\
\hline \multicolumn{4}{|c|}{ Strong points } \\
\hline $\begin{array}{l}\text { 1.Implemented e-learning } \\
\text { system }\end{array}$ & $\begin{array}{l}\text { 1. Implemented e-learning } \\
\text { system }\end{array}$ & 1.Study mobility & $\begin{array}{l}\text { 1.University has an } \\
\text { extension unit }\end{array}$ \\
\hline $\begin{array}{l}\text { 2. Appropriate } \\
\text { infrastructure for practical } \\
\text { aptitudes }\end{array}$ & $\begin{array}{l}\text { 2. Appropriate infrastructure } \\
\text { for practical aptitudes }\end{array}$ & $\begin{array}{l}\text { 2. Appropriate infrastructure } \\
\text { for practical aptitudes }\end{array}$ & $\begin{array}{l}\text { 2. Appropriate } \\
\text { infrastructure for practical } \\
\text { aptitudes }\end{array}$ \\
\hline $\begin{array}{l}\text { 3.Functional relationships } \\
\text { with graduates and } \\
\text { employees }\end{array}$ & $\begin{array}{l}\text { 3.Students' involvement in } \\
\text { research activity }\end{array}$ & $\begin{array}{l}\text { 3.Functional relationships } \\
\text { with graduates and employees }\end{array}$ & $\begin{array}{l}\text { 3.Functional relationships } \\
\text { with graduates and } \\
\text { employees }\end{array}$ \\
\hline $\begin{array}{l}\text { 4. Good representativeness } \\
\text { of students within the } \\
\text { university management } \\
\text { structures (Senate, } \\
\text { Faculties' Councils) }\end{array}$ & $\begin{array}{l}\text { 4. Good representativeness } \\
\text { of students within the } \\
\text { university management } \\
\text { structures (Senate, Faculties' } \\
\text { Councils) }\end{array}$ & $\begin{array}{l}\text { 4. Good representativeness of } \\
\text { students within the university } \\
\text { management structures } \\
\text { (Senate, Faculties' Councils) }\end{array}$ & $\begin{array}{l}\text { 4. Good representativeness } \\
\text { of students within the } \\
\text { university management } \\
\text { structures (Senate, } \\
\text { Faculties' Councils) }\end{array}$ \\
\hline $\begin{array}{c}\text { 5.Quality system } \\
\text { implemented at students' } \\
\text { level }\end{array}$ & $\begin{array}{c}\text { 5.Quality system } \\
\text { implemented at students' } \\
\text { level }\end{array}$ & 5.Big number of students & 5.Head-hunting activity \\
\hline \multicolumn{4}{|c|}{ Weak points } \\
\hline $\begin{array}{l}\text { 1. No ECTS procedures for } \\
\text { voluntaries activity. }\end{array}$ & $\begin{array}{l}\text { 1. Weak representativeness } \\
\text { of voluntaries activities. }\end{array}$ & $\begin{array}{l}\text { 1. Deficiencies in ECTS and } \\
\text { textbooks supports. }\end{array}$ & $\begin{array}{l}\text { 1. Deficiencies professional } \\
\text { training preparation. }\end{array}$ \\
\hline $\begin{array}{l}\text { 2.The individual } \\
\text { professional training stage } \\
\text { is not recognized }\end{array}$ & $\begin{array}{l}\text { 2. Deficiencies on organizing } \\
\text { of secretariat activity }\end{array}$ & $\begin{array}{l}\text { 2.Deficiencies in professional } \\
\text { training activity }\end{array}$ & $\begin{array}{l}\text { 2.Low number of eternal } \\
\text { mobility }\end{array}$ \\
\hline $\begin{array}{l}\text { 3.Weak promotion of the } \\
\text { centre for education in } \\
\text { career }\end{array}$ & $\begin{array}{l}\text { 3.Weak development o of } \\
\text { relationship with employers }\end{array}$ & $\begin{array}{l}\text { 3. Need to improve the } \\
\text { relationship with employers }\end{array}$ & $\begin{array}{l}\text { 3.Weak development } \\
\text { o of relationship with } \\
\text { employers }\end{array}$ \\
\hline $\begin{array}{l}\text { 4.Deficiency in } \\
\text { organizing students' } \\
\text { representativeness }\end{array}$ & $\begin{array}{l}\text { 4.Deficiency in organizing } \\
\text { students' representativeness }\end{array}$ & $\begin{array}{l}\text { 4.Deficiency in organizing } \\
\text { students' representativeness }\end{array}$ & $\begin{array}{l}\text { 4. Weak informatics } \\
\text { competencies }\end{array}$ \\
\hline $\begin{array}{l}\text { 5.Deficiency in social } \\
\text { activities management }\end{array}$ & $\begin{array}{l}\text { 5.Lack of appropriate study } \\
\text { spaces }\end{array}$ & $\begin{array}{l}\text { 5.Lack of appropriate study } \\
\text { spaces }\end{array}$ & $\begin{array}{l}\text { 5.Inability of using } \\
\text { specific software }\end{array}$ \\
\hline \multicolumn{4}{|c|}{ Opportunities } \\
\hline
\end{tabular}

1. Alignment to Bologna system

2. Intensifying the activities of long-life learning

3.Partenerships and international cooperation

4. Intensifying the research - innovation activities where students are involved

$\begin{array}{ccc}\begin{array}{c}\text { 5. Launching new study } \\ \text { programs in English and }\end{array} & \begin{array}{c}\text { 5. High attractiveness of some } \\ \text { study programmes (MV, TPPA, }\end{array} & \begin{array}{c}\text { 5. Launching new study } \\ \text { programs in English and }\end{array} \\ \text { French } & \text { CEPA...) } & \text { French }\end{array}$

\section{Threats}

1. Lack of stabile legislation.

2. Lack of appropriate of founding from state budget and financial difficulties of private environment, who, in this way, has not capacity of supporting higher education.

3. Concurrency on the market of university educational programmes providers.

4. Demographic decrease.

5. Increased dropout after first two years of study. 
and intensifying the research - innovation activities where students are involved.

We record divergent points of view between universities (Table 1), except UASVM Bucharest, where we have no available data, concerning launching new study programs in English and French (UASVM Cluj-Napoca and Timisoara) and high attractiveness of some study programmes - MV, TPPA, CEPA - (UASVM Iasi).

Threats. We find that UASVM Cluj - Napoca vision concerning threats coincides with UASVMs Iasi and Timisoara, and for this reason we generalized the components of the threats also for UASVM Bucharest (Tab. 1). Thus, the main threats in vision of the student assessors, may be synthetized, as follows: lack of stabile legislation (the existing one does not stimulate the recruitment of young teaching staff), lack of appropriate of founding from state budget (with repercussions on both teaching staff motivation, and material supplying needed for educational process) and financial difficulties of private environment, who, in this way, has not capacity of supporting higher education, concurrency on the market of university educational programmes providers (competition with private strong university centres, from Romania and also abroad), demographic decrease și increased dropout after first two years of study (incapacity of financial support, incertitude of the labor market, etc.).

Based on the SWOT Analyse we elaborated by synthetizing contributions of the students assessors from the university centres involved in this study, we may draw the starting premises for improving and developing the appropriate strategies for each quality system from mentioned UASVMs.

Thus, for UASVM Cluj-Napoca, which has good performances concerning the implementation of the e-learning system, quality system implemented at students' level and functional relationships with graduates and employees, we recommend to concentrate its efforts towards the improvement of the voluntaries activities, enhancement of the students commitment for scientific research, and students' representativeness, especially for improving the activity of the centre of education for career, and also of social activities management. UASVM Bucharest, starting from an appropriate implementation of the e-learning and quality systems, and also of research activity in students' community, should concentrate its strategy towards the progress in the voluntaries activities, the management of the support activities destined to students, but mainly on development of the system of relationships with employers.

In UASVM Iasi we not the institution performances concerning the external study mobility (ERASMUS, AUEF, DAB, etc.), the big number of students included in universities' educational programmes, and also functional relationships with graduates and employers. In this context, we consider that the strategy of the university must aim, mainly, besides organizing issues, the improvement of ECTS and relationships with employers at both, communication and implementation levels, Concerning UASVM Timisoara, by good functioning of the relationships with graduates and employers, the presence of an extension unit and head-hunting activity, it has remarkable performances, and for this reason we consider that future strategies must be directed towards improvement of the professional training programmes destined to students, development of the external mobility, and taking actions for enhancing the students' abilities in using the available informatics portfolio.

By implementing the suggestions on strategies for each analysed higher education institution, they will take advantage of existing opportunities, in an adequate manner, simultaneously with reinforcing their ability to handle obstacles faced in the context of Romanian realities, but also to those existing at global level.

\section{CONCLUSIONS}

From the overall picture of the component for the involvement of students in quality assurance process in UASVMs from our country, it appears that the whole assembly of these specific universities included in this analysis reached a remarkable performance with strong points that are relevant and consistent for the quality system, weak points aiming mainly easily remediable issues not fundamental, opportunities and threats perceived similar by institutions involved in the study.

The highlighting of the strengths, weaknesses, opportunities, and threats of the agricultural and veterinary higher education representative at national level, demonstrates that, in the opinion 
of students, it has a uniform functionality, but keeping note of specificity associated with each university centre profile.

The SWOT Analysis emphasizes the functionality of the quality system in Universities of Agricultural Sciences and Veterinary Medicine Cluj-Napoca, Iasi, Timisoara, and Universities of Agronomic Sciences and Veterinary Medicine Bucharest, where the specific component of student assessors involvement have adequate importance, and it helps to improvement and development of strategic visions in approached institutions.

\section{REFERENCES}

1. Bratean D, Ilie L, Dragan M (2013). A Conceptual Framework for the Implementation of Total Quality Management in Higher Education, Managerial Challenges of the Contemporary Society: 195-200.

2. Brătianu C, Miroiu A (1999). Politica de asigurare a calității, Ars Ducendi, București.

3. Brătianu C. (2000). Managementul calității în învățământul superior, Vasile Goldiș University Press, Arad.

4. Elliott KM, Shin D (2002). Student Satisfaction: An Alternative Approach to Assessing this Important Concept. Journal of Higher Education Policy and Management, 24 (02): 197-209.

5. Fayol F (1979). .Administration industrielle et generale, Dunod, Paris

6. Federkeil G (2008). Rankings and Quality Assurance in Higher Education, Higher Education in Europe, 33: 2, 219 - 231. http://dx.doi.org/10.1080/037977208022 54023

7. Ivorschi R (2012). The Evolution of Romania's Gross Domestic Product in the Last Ten Years, Revista de Statistica. http://www.revistadestatistica.ro/ Articole/2012/ art6en_rrs_5_2012.pdf

8. Georgevia P (2008). Asigurarea interna a calitatii în cadrul institutiilor de învatamânt superior, Ghid, WYG International, Bucuresti.
9. Juran JM (2000). Planificarea calității, Teora, București

10. McCaskey J and Kyeyune C (2010). Demographic and Attitudinal Factors Influencing Doctoral Student Satisfaction, Sabina Nwenyi, Timothy Baghurst, Canadian Social Science, 9 (6): 47-56

11. Sum S, McCaskey J, Kyeyune C (2008). A survey research of satisfaction levels of graduate students enrolled in a nationally ranked top-10 program at a mid-western university, Research in Higher Education Journal

12. *** (2009). European Association for Quality Assurance in Higher Education. ENQA Report on Standards and Guidelines for Quality Assurance in the European Higher Education Area, Standards and Guidelines for Quality Assurance in the European Higher Education Area, Helsinki, Finland. www.enqa.eu/wp-content/.../ ESG_3edition-2.p

13. *** (2012). European Student Union Report. ESU Student Centered Learning Toolkit. Timea for a Paradigm Change. European Univeristy Association www.esu-online. org/.../100814-SCL.pdf

14. *** (2012). European Commission, Key data On education in Europe, (C) Education, Audiovisual and Culture Executive Agency, eacea.ec.europa.eu/education/ eurydice/ documents/key_data./134en.pdf

15. http://www.aracis.ro/fileadmin/ARACIS/Publicatii Aracis/brosuri/brosura_USMAV_pt._BT.pdf

16. http://proiecte.aracis.ro/fileadmin/ARACIS/Publicatii_ Aracis/Brosuri_proiect/Etapa_III/Brosuri_proiect/ Aracis_46_interoir_mail.pdf

17. http://proiecte.aracis.ro/fileadmin/ARACIS/Publicatii Aracis/Brosuri_proiect/Etapa_II/Brosuri_proiect/Aracis_ Interior_Med_Vet_Cluj_34_mail_2.pdf

18. http://www.aracis.ro/uploads/media/Raport_Director_ de_misiune_si_coordonator_81.pdf

19. http://mobile.www.aabri.com/manuscripts/09403.pdf

20. http://vrtl12546.servidoresdns.net/sites/default/files/ rankings-and-quality-assurance-higher-edu http://www. invatamant-superior.ro/wp-content/uploads/2013/08/ Analiza-Functionala-a-Sectorului-cation.pdf

21. http://vrtl12546.servidoresdns.net/sites/default/files/ rankings-and-quality-assurance-higher-education.pdf 